\title{
Digital technologies in civic and patriotic education of students
}

\author{
Svetlana Fedorova*, Daria Ivanova, and Ksenia Balysheva \\ Mari State University, 424001, Yoshkar-Ola, Russia
}

\begin{abstract}
The study deals with the problem of the effectiveness of digital technologies use in the civic and patriotic education of students. The relevance of the identified problem in the current conditions of social development is stated. The events of recent years show how important it is to solve the problems of civic and patriotic education of young people promptly. The implementation of the tasks of forming a citizen and a patriot should be carried out at all levels of the education system. The astudy analyzes the available material on digital support of the education system such as 3D games, teletandem, podcasts, social networks, video resources, and other innovative technologies for implementing e-learning. The methods and results of an empirical study are presented to assess the level of civic and patriotic development of student personality and to analyze the possibilities of using digital technologies in this respect. The digital technologies that can be used to solve the problem are described: a systematized bank of digital tools, the control and evaluation component and the activity component. The authors analyze their electronic educational resources. Conclusions are drawn about the effectiveness of the use of digital tools in the civic and patriotic education of students. It is stated that the modern approach to the civil-patriotic education of students involves the use of new technologies that meet their interests and preferences. Digital technologies have considerable didactic opportunities and their potential requires wide application in the educational process of the university.
\end{abstract}

\section{Introduction}

The problem of the civic and patriotic education of young people is of concern to scientists in almost all countries. This is due to the fact that civic consciousness and patriotism are integral characteristics of a strong, unified, and full-fledged state. From an early age, a person should be brought up in the spirit of respect for the achievements of their country and pride in its culture. The ideological structure of society is the basis of understanding and common ground [1]. The integrity of the unity of the territory and other components (language, traditions, culture, etc.) gradually forms a sense of patriotism which is love for a small homeland as well as civic consciousness of a representative of a certain country.

Alternatively, civic consciousness and patriotism are the necessary conditions for the existence of any society. It is a challenging task to separate patriotism from civic

\footnotetext{
* Corresponding author: svetfed65@rambler.ru
} 
consciousness as patriotism determines the development of the individual as a citizen. Without patriotism, it is impossible to develop a sense of personal and social significance [2]. Without love for the motherland, it is impossible to fully realize your citizenship.

The events of recent years that take place globally show how important it is to solve the problems of civic and patriotic education of young people promptly. Moreover, the implementation of the tasks of forming a citizen and a patriot should be carried out at all levels of the education system, taking into account the age characteristics of children.

The education of a citizen and a patriot in the university environment involves the use of a variety of productive methods and techniques, both traditional and innovative. The latter include digital technologies. In general, digitalization is a kind of challenge for the modern education system, aimed at improving the educational process [3]. The didactic potential of digital technologies in the implementation of learning tasks is analyzed in detail by modern authors $[4,5]$. The final result of university training that includes digital services and technologies should be the successful self-determination of a graduate in the digital world [6]. For this purpose, the university education system uses a variety of digital technologies such as 3D games, teletandem, podcasts, social networks, video resources, interactive features of Web 2.0 services [7], and other innovative technologies for implementing elearning [8].

The age of digital technologies opens up wide opportunities for the development of civic and patriotic qualities of students. Among them, there are new educational tools that meet the needs of students, new types of activities that take into account their interests, etc. This study is aimed at revealing the effectiveness of the use of digital technologies in the civic and patriotic education of university students.

\section{Materials and Methods}

First of all, we analyzed the psychological and pedagogical literature on the problem of the use of information technologies in the civic and patriotic education of students. Recent studies have highlighted the need for the use of Internet technologies in the education of a citizen and a patriot. At present, the younger generation is completely absorbed in social networks, and the only way to interest them in the achievements of the state and society is to convert the traditional format of information presentation into a "digital" one [9]. Such forms of work as the creation of websites on patriotic themes, the implementation of online projects on civic and patriotic education, and the development of public associations in social networks can be used for developing civic and patriotic qualities in modern young people [10].

The problem of using digital technologies in the civic and patriotic education of young people is studied not only by scientists but also by practitioners. Government bodies also contribute to this process. Thus, the Portuguese government points out the importance of educating a patriot and a citizen of their country through the use of information technologies to form these qualities in young people [11]. The development of patriotic websites as well as the active involvement of students in the development of such websites and other digital resources increase the level of civic and patriotic consciousness of the younger generation.

In Kazakhstan, the emphasis is placed on the national values of the citizen, in connection with which digital tools of ethnic orientation are developed and used such as games, web quests, information and educational resources [12].

Russia has also accumulated extensive experience in the use of information and communication technologies in the civic and patriotic education of young people. There are various kinds of Internet contests, for example, the annual international Internet contest "Page 
of Family Glory", where everyone can participate in writing an e-book about the hero people, feats, and historical events of the country [13]. There are a large number of patriotic competitions and contests in which students can participate remotely ("My country is my Russia", "Cities of Military Glory", "Glory of Russia"), etc. There is an open bank of digital resources that can be used in the extra-curricular activity (the sites of the Immortal Regiment of Russia, the generalized data bank "Memorial", the electronic document bank "The Feat of the People in the Great Patriotic War of 1941-1945", Rospatriotcenter, etc.).

To assess the level of civic and patriotic development of students' personalities and analyze the possibilities of using digital technologies in this process, we conducted an empirical study with the students of the Federal State Budgetary Educational Institution of Higher Education "Mari State University". The experiment was attended by 150 first to thirdyear students of the pedagogical training. The questionnaire included open-ended and closedended questions on the subject of the study.

\section{Results}

The respondents' definition of themselves as a "patriot" helped to identify motivational characteristics of the behavioral nature of the respondents, namely, 38.3\% compared the concept of "patriot" with "willingness to defend their homeland", $20.8 \%$ correlated a patriot with a person who finds it sufficient to love their homeland, $20 \%$ associated the term "patriot" with "a law-abiding citizen", $11.7 \%$ stated that being a patriot means "being socially active in the interests of their country and people", for $9.2 \%$ to be a patriot "it is enough to be proud of the country". Thus, the younger generation perceives a patriot as a person with an active life position, ready to stand up for their homeland. More than half of the respondents identified themselves as a "patriot of Russia" (63.3\%), worried about its future and effective development. The majority of the respondents (93.3\%) gave a positive answer to the question about the desire to personally participate in solving the problems of the country. Although some respondents believe that this process is outside their control (45.8\%), and $54.2 \%$ of the respondents think that they are quite ready to change the life of the country for the better.

The data obtained on the future of the country are noteworthy: 1) $60 \%$ of the students believe that Russia will overcome all difficulties and will flourish; 2) 22\% of the respondents believe that Russia will exist as it is today; 3) 9\% are pessimistic about Russia's future, having choosen the answer "Russia is on the way toward disintegration»; 4) 9\% of young people found this question difficult to answer.

When assessing patriotic sentiments among their immediate circle, $60 \%$ of the respondents agree that most of their immediate circle are patriots, $21.1 \%$ believe that there are few patriots in their circle, and $18.9 \%$ of respondents found it difficult to assess.

The formation of civic and patriotic consciousness is influenced by a number of factors of an objective and subjective nature. Among the objective (macro) factors that determine the level of civic and patriotic consciousness, the following can be distinguished: 1) the political and economic situation in the world; 2) the political and economic situation in the country; 3 ) religion, history, and national values; 4) information coming from the media.

Subjective (micro) factors include our own beliefs, patriotic upbringing in the family, and the opinion of our closest referents.

Table 1 shows the results of the respondent ranking of these factors.

Table 1. Factors of patriotic consciousness formation (according to the respondents).

\begin{tabular}{|l|c|}
\hline Factors & Rank \\
\hline Patriotic education in the family, friends' and relatives' opinions & 1 \\
\hline
\end{tabular}




\begin{tabular}{|l|l|}
\hline A person's own beliefs & 2 \\
\hline Religion, history, and national values & 3 \\
\hline $\begin{array}{l}\text { Information from the media (the Internet, TV, radio, newspapers, and } \\
\text { magazines) }\end{array}$ & 4 \\
\hline Political and economic situation in the country & 5 \\
\hline Political and economic situation in the world & 6 \\
\hline
\end{tabular}

According to the respondents, the most relevant are the subjective factors that determine the formation of civic and patriotic consciousness of young people.

The research determined the effectiveness of various forms of civic and patriotic education of students conducted as part of extracurricular activities. Students highly appreciated historical and cultural events (37.5\%), methods and techniques for preserving the historical memory of the Great Patriotic War (33.3\%). They also noted the importance of using the Internet and digital resources in a civil-patriotic direction (29.2\%).

Noteworthy answers were received on the question of the most "patriotic" groups of the population (see Table 2).

Table 2. The most "patriotic" groups of the population (according to the respondents).

\begin{tabular}{|l|l|c|}
\hline № & Groups of population & \% of the respondents \\
\hline 1 & Military men & 23.3 \\
\hline 2 & Politicians & 20.8 \\
\hline 3 & Retired people & 17.5 \\
\hline 4 & Civil servants & 13.3 \\
\hline 5 & Young people & 9.2 \\
\hline 6 & Specialists (doctors, teachers, engineers, lawyers, etc.) & 6.7 \\
\hline 7 & Workers (builders, locksmiths, etc.) & 3.3 \\
\hline 8 & Businessmen and entrepreneurs & 3.3 \\
\hline 9 & Managers (company directors, department heads, etc.) & 2.5 \\
\hline
\end{tabular}

According to the respondents, military men (23.3\%), politicians (20.8\%), and retired people $(17.5 \%)$ have the highest degree of maturity of civic and patriotic feelings. These categories of the population are associated with the true bearers of cultural values and traditions of the country. However, the fact that young people are placed only in the fifth position (9.2\%) with teachers and doctors being in the sixth position (6.7) is disappointing and makes us think about the self-assessment of our patriotic consciousness.

The analysis of Russian patriotism from a nationality perspective is quite noteworthy. Thus, $82 \%$ of the respondents believe that patriotism is more developed in the territories where the majority of the Russian population lives. $18 \%$ of the young people believe that patriotism is more developed in ethnic republics and regions of Russia. At the same time, $21 \%$ of respondents say that "it would be good if representatives of one nationality lived in Russia" while 79\% support the multinational composition of the Russian population.

The second part of the survey was devoted to determining the degree of the acquaintance of the respondents with civic and patriotic digital resources. When asked what they mean by digital resources, most of the respondents named presentations (35.8\%), the Internet (31.7), and websites $(28.3 \%) .4 .2 \%$ of the respondents found it difficult to answer this question. It was even more difficult for the students to name civic and patriotic digital resources. $50.8 \%$ of the respondents could only name Internet sites and Wikipedia, while the rest (49.2\%) did not answer this question. 


\section{Discussion}

To revise the results obtained on the level of civic and patriotic consciousness of students, we systematized the bank of digital tools. In the bank, we included the materials of the knowledge component (the theoretical material accompanied by the multimedia content), the control and evaluation component (the diagnostic material for checking the correctness of the learned material and evaluating the effectiveness of resources), and the activity component (practical tasks aimed at developing resources and tools of civic and patriotic orientation).

Next, we used the resources that we previously created, in particular, the electronic educational resource "Culture and Life of the Mari people" which includes the following topics: "the Mari national costume", "Mari national dishes", "the Mari folklore», «Mari folk musical instruments", "the Mari dance". Each section presents the informative material that is accompanied by the video and audio content. After each topic, there is a diagnostic material that allows you to identify the level of acquisition of the studied material and the correctness of its perception by the student. At the end of the entire course, there is a final test that includes questions on all the topics. This resource is effectively used both in class and in extracurricular activities as well as when students work independently.

Virtual excursions are one of the most effective resources for the civic and patriotic education of students. Now there are a large number of museum sites that use this tool. For example, the website of the Timofey Evseev National Museum of the Republic of Mari El offers a great number of virtual excursions. The excursions give information about the notables of the republic, show everyday objects of the Mari people and exhibits of decorative and applied art, etc. Virtual tours provide an opportunity to visit museums of other cities and countries and are an effective means of forming students' civic and patriotic qualities.

We have also developed virtual ethnotourist routes for civic and patriotic education of students, for example, the resource "The ethnotourist space of the Republic of Mari El" [14]. It should be noted that ethnotourism which is considered to be an introduction to the way of life and national culture of an ethnic community has a high potential in terms of forming an active civic position and patriotic feelings of modern young people. Virtually visiting different cities of the Republic of Mari El and Russia, getting acquainted with ethnic landmarks, historical and cultural sights, students feel the national pride in their native land and feel responsible for preserving and developing its culture, people, customs and traditions, etc.

It should be noted that in our work on the formation of civil and patriotic consciousness of the students we gave preference to the digital services which include interaction and enable students and researchers to achieve high results in this respect [15].

\section{Conclusion}

The modern approach to the civic and patriotic education of students involves the use of new technologies that meet their interests and preferences. To form the theoretical concepts, you can use various websites, electronic educational resources, and digital data banks; to control the acquired knowledge, you can organize Internet contests, competitions, and web quests; to form practical skills you can include the tasks based on developing software products, digital and video resources, etc. Digital technologies have considerable didactic opportunities and their potential requires their wide application in the educational process of the university. 


\section{References}

1. S. Uzakbayeva, Sh. Zhalgasova, A. Beisembayeva, G. Kosherbayeva, Procedia - Social and Behavioral Sciences 141, 675-679 (2014). ISSN 1877-0428, https://doi.org/10.1016/j.sbspro.2014.05.118.

2. D. Omelchenko, S. Maximova, G. Avdeeva, Procedia - Social and Behavioral Sciences 190, 364-371 (2015) ISSN 1877-0428, https://doi.org/10.1016/j.sbspro.2015.05.012.

3. A.A. Eltemerov, S.N. Fedorova, The use of digital technologies in the professional training of cadets, I International conference (ASEDU-I 2020), Advances in science, engineering and digital education, Journal of Physics: Conference Series, IOP Publishing 1691, 012214 (2020) doi:10.1088/1742-6596/1691/1/012214.

4. S.D. Karakozov, N.I. Ryzhova, Journal of Siberian Federal University, Humanities \& Social Sciences 12(9), 1635-1647 (2019) doi: 0.17516/1997-1370-0485.

5. F.K.M. Arif, N.Z. Zubir, M. Mohamad, M.M. Yunus, Humanities and Social Sciences Reviews 7(4), 203-213 (2019) doi: 10.18510/hssr.2019.7426.

6. A.V. Perig, Eurasia Journal of Mathematics, Science and Technology Education 14, em1632 (2018) doi: 10.29333/ejmste/97188.

7. E.N. Dronova, Bulletin of the Moscow City Pedagogical University. Series: Informatics and Informatization of Education 4(46), 40-49 (2019) doi: 10.25688/20729014.2018.46.4.04.

8. Y. Hao, K.S. Lee, Computers in Human Behavior 48, 1-8 (2015) doi: 10.1016/j.chb.2015.01.028.

9. S.G. Mashkova, Current problems of the humanities and natural sciences 8(2), 144-146 (2014)

10. E. Lacka, T.C. Wong, Yacine Haddoud M., Computers \& Education 163, (2021). ISSN 0360-1315, doi.org/10.1016/j.compedu.2020.104099.

11. H. Santos, J. Batista, R.P. Marques, Procedia Computer Science 164, 123-130 (2019) ISSN 1877-0509, doi.org/10.1016/j.procs.2019.12.163.

12. Z. Tolen, S. Tulenova, E. Assyltaeva, N. Aitymbetov, Procedia - Social and Behavioral Sciences 116, 4859-4863 (2014. ISSN 1877-0428, doi.org/10.1016/j.sbspro.2014.01.1038.

13. V.V. Chirkova, L.N. Chirkova, Modern information technologies and information technology education 11, 384-387 (2015)

14. S.N. Fedorova, V.I. Toktarova, V.V. Konstantinova, E.M. Vorontsova, E.V. Alekseeva, Etnotourism as the means of civil and patriotic education, Proceedings of SOCIOINT 2017- 4th International Conference on Education, Social Sciences and Humanities 10(12), 130-133 (2017).

15. J. Hilliard, K. Kear, H. Donelan, C. Heaney, Computers and Education 103675 (143), (2020) doi: 10.1016/j.compedu.2019.103675. 